\title{
Raised arterial pressure in parents of proteinuric insulin dependent diabetics
}

\author{
G C VIBERTI, H KEEN, M J WISEMAN
}

\begin{abstract}
Arterial pressure is raised early in the subset of insulin dependent diabetics at risk of later development of progressive renal failure, suggesting that liability to arterial hypertension may play a part in the aetiology of diabetic kidney disease. Evidence for a genetic basis was therefore sought by measuring the blood pressures of the 26 surviving parents of 17 insulin dependent diabetic patients with proteinuria and comparing them with those of the parents of 17 matched insulin dependent diabetic patients without proteinuria selected from the same cohort.

Systolic and diastolic pressures were significantly higher in parents of the proteinuric (mean (SD) $161(27) / 94(14) \mathrm{mm} \mathrm{Hg}$ ) than in parents of the non-proteinuric patients $(146(21) / 86$ (11) $\mathrm{mm} \mathrm{Hg}$ ). The difference between the sample mean blood pressures was $15 \mathrm{~mm} \mathrm{Hg}$ (95\% confidence interval 3.3 to $26.7 \mathrm{~mm}$ $\mathrm{Hg}$ ) for systolic pressure and $8 \mathrm{~mm} \mathrm{Hg}(95 \%$ confidence interval 0.8 to $15.2 \mathrm{~mm} \mathrm{Hg}$ ) for diastolic pressure. These differences were independent of age, sex, and adiposity. There was a significant correlation between the mean arterial pressures in the proteinuric patients and the higher mean blood pressure in their parents.

High blood pressure in non-diabetic parents may be a marker of susceptibility to clinical nephropathy in their insulin dependent diabetic offspring.
\end{abstract}

\section{Introduction}

Why the risk of clinical proteinuria and renal failure is restricted to only $30-40 \%$ of patients with insulin dependent diabetes mellitus is not known. ${ }^{1-5}$ Genetic determinants for susceptibility to nephropathy have been suspected but reports of associations between diabetic

\footnotetext{
Unit for Metabolic Medicine, United Medical and Dental Schools of Guy's and St Thomas's Hospitals, Guy's Hospital, London SE1 9RT

G C VIBERTI, MD, MRCP, senior lecturer in medicine

H KEEN, MD, FRCP, professor of human metabolism

M J WISEMAN, MRCP, honorary senior registrar

Correspondence to: Dr Viberti.
}

microangiopathy and genetic markers such as components of complement, immunoglobulin heavy chain phenotypes, and HLA antigens are controversial or unconfirmed..$^{6-9}$

The proteinuria of established diabetic nephropathy is associated with arterial hypertension and it has generally been assumed that the higher arterial pressure is directly related to the renal failure. ${ }^{1011}$ The relation, however, may be more complex. ${ }^{12}$ Substantially raised blood pressure is recorded in insulin dependent diabetics with microalbuminuria, ${ }^{13-15}$ at high risk of later clinical nephropathy,,$^{14-16}$ but lacking any evidence of impaired renal function. This raised blood pressure may therefore be not a consequence of renal disease but rather an independent marker of liability to hypertension conferring susceptibility to renal disease if diabetes is present.

If liability to diabetic nephropathy was determined by the possession of the genetic components of raised arterial pressure the presence of relative hypertension in the parents of patients with diabetic nephropathy could be predicted. ${ }^{17}$ We tested this hypothesis by measuring the blood pressures in the parents of proteinuric and matched non-proteinuric insulin dependent diabetic patients.

\section{Subjects and methods}

During a family study of diabetes standardised biometric and clinical data were recorded in diabetic patients and their parents. ${ }^{12} \mathrm{~A}$ single measurement of arterial blood pressure to the nearest $5 \mathrm{~mm} \mathrm{Hg}$ (phase I/IV) was recorded by one of three observers using a standard mercury sphygmomanometer on the right arm with the subjects seated after 10 minutes' rest. Fresh urine (5 $\mathrm{ml}$ ) was tested for protein by mixing with $0.5 \mathrm{ml}$ salicylsulphonic acid $10 \%$ ( $w / / v o l)$ in water. A urinary protein concentration exceeding $0.15 \mathrm{~g} / \mathrm{l}$ gives visible turbidity. ${ }^{18}$ Samples were graded as negative or as trace to ++ positive with increasing turbidity. In the parents urine was also tested for glucose one hour after a $50 \mathrm{~g}$ oral glucose load.

Of the 221 insulin dependent diabetics identified, 31 (17 male, 14 female) were positive for proteinuria. Their mean age was $29 \cdot 7$ years (range 12-55) and mean duration of diabetes 16.1 (SD 6.4) years. In 17 cases 26 parents were available for blood pressure measurements. None of the parents had proteinuria; two were diabetic but the remainder were free of glycosuria after the glucose test load. A series of 17 insulin dependent diabetic patients without proteinuria was selected from the same cohort and matched with the proteinuric propositi for age (within four years), duration of diabetes (within two years), parental state, and sex. None of the parents of these 17 nonproteinuric diabetic controls had proteinuria; one was diabetic but all the 
others were free of glycosuria after the glucose challenge. Table I gives the clinical features of the two groups of 17 insulin dependent diabetic patients.

In addition, we compared all cause mortality in the parents of all 31 proteinuric patients with that in the parents of all 132 non-proteinuric diabetics falling within the same age range (12-55). Vital state was ascertainable for 54 of the 62 parents of the proteinuric group and for all 264 parents of the non-proteinuric diabetics.

TABLE I-Clinical features of 17 proteinuric (propositi) and 17 matched non-proteinuric (controls) insulin dependent diabetic patients with recorded parental blood pressure. Values are means ( $S D$ or range in parentheses)

\begin{tabular}{lcc}
\hline & Propositi & Controls \\
\hline Sex & $7 \mathrm{M} / 10 \mathrm{~F}$ & $8 \mathrm{M} / 9 \mathrm{~F}$ \\
Age (years) & $26 \cdot 9(12-41)$ & $26 \cdot 4(15-49)$ \\
Height (cm) & $163(8 \cdot 7)$ & $166(9 \cdot 5)$ \\
Weight (kg) & $59 \cdot 8(10 \cdot 4)$ & $64 \cdot 8(9 \cdot 5)$ \\
Duration of diabetes (years) & $16 \cdot 5(5 \cdot 0)$ & $15 \cdot 5(5 \cdot 1)$ \\
Systolic blood pressure (mm Hg) & $135(25)$ & $125(15)$ \\
Diastolic blood pressure (mm Hg) & $87(11)$ & $82(9)$ \\
\hline
\end{tabular}

Statistical analysis-The significance of differences was assessed by the paired $t$ test and differences between sample means expressed with $95 \%$ confidence intervals. Correlation was analysed by linear regression using the least squares method and mortality compared by logistic regression analysis ${ }^{19}$ with the GLIM (generalised linear interactive modelling) statistical package (Rothamsted Experimental Station, Harpenden, 1978). The odds ratio for mortality was calculated by the maximum likelihood method ${ }^{19} \mathrm{after}$ correction for the patient's sex, age, and duration of diabetes and for parental age and sex.

\section{Results}

Parental arterial pressure-Mean systolic and diastolic pressures were significantly higher $(p<0.02$ and $p<0.05)$ in the parents of the 17 proteinuric than in the parents of the 17 non-proteinuric diabetics (table II). The mean

TABLE II-Clinical features and blood pressure in parents of 17 proteinuric (propositi) and 17 non-proteinuric (controls) insulin dependent patients. Values are means (SD or range in parentheses)

\begin{tabular}{lcc}
\hline & $\begin{array}{c}\text { Parents of } \\
\text { propositi }\end{array}$ & $\begin{array}{c}\text { Parents of } \\
\text { controls }\end{array}$ \\
\hline Sex & $11 \mathrm{M} / 15 \mathrm{~F}$ & $11 \mathrm{M} / 15 \mathrm{~F}$ \\
Age (years) & $56 \cdot 2(41-77)$ & $57 \cdot 1(41-81)$ \\
Body mass index & $25 \cdot 4(3 \cdot 9)$ & $24 \cdot 9(3 \cdot 3)$ \\
Systolic blood pressure (mm Hg) & $161(27) \dagger$ & $146(21)$ \\
Diastolic blood pressure (mm Hg) & $94(14) \ddagger$ & $86(11)$ \\
\hline
\end{tabular}

$\star$ Body mass index calculated as weight $(\mathbf{k g}) /$ height $(\mathbf{m})^{2}$.

tp $<0.02, \neq \mathrm{p}<0.05$ Compared with control parents.

difference ( $95 \%$ confidence interval) between the two groups was $15 \mathrm{~mm} \mathrm{Hg}$ $(3.3$ to $26.7 \mathrm{~mm} \mathrm{Hg})$ for systolic and $8 \mathrm{~mm} \mathrm{Hg}(0.8$ to $15.2 \mathrm{~mm} \mathrm{Hg})$ for diastolic pressure. The two groups of parents were closely similar in respect of age, sex distribution, and body mass index. As either parent may be responsible for the transmission of raised arterial pressure the data were also analysed by using only the higher parental blood pressure when both had been measured (nine patients in each group) and the single value when only one was available. These two subsets of 17 parents of proteinuric and nonproteinuric patients were similar in sex distribution (six male, 11 female $v$ three male, 14 female), mean age (57 (SD 11) v 58 (10) years), and mean body mass index $(25 \cdot 7$ (SD 4.4) $v 25.0(3 \cdot 9)$ ). Mean blood pressure (diastolic pressure plus one third of the pulse pressure) in these subsets of parents was on average significantly higher in parents of proteinuric than in parents of non-proteinuric diabetics (mean 122 (SD 17) $v 111$ (11) $\mathrm{mm} \mathrm{Hg} ; \mathrm{p}<0.02$ ) (figure). There was a significant correlation $(r=0.70 ; p<0.01)$ between the mean blood pressures of the 17 proteinuric patients and the higher mean blood pressure in their parents. This correlation did not reach significance $(r=0.39)$ for the non-proteinuric patients.

Parental mortality-Of the parents of the 31 proteinuric diabetic patients, $14(25 \cdot 9 \%)$ were known to be dead compared with $51(19 \cdot 3 \%)$ of the parents of the 132 non-proteinuric patients. The risk of death in parents of nonproteinuric diabetics was 0.58 times $(95 \%$ confidence interval 0.20 to 1.68 ) that in parents of proteinuric diabetics; this difference was not significant.

\section{Discussion}

Though more than $90 \%$ of all insulin dependent diabetics suffer some renal structural damage, ${ }^{20}$ cohort studies suggest that only a minority-albeit a large minority-ever become proteinuric and progress to renal failure. A substantial proportion escape this outcome, even after 40 years of diabetes. ${ }^{12}$ Inadequate control of the diabetic state contributes to the liability to renal failure but other, poorly understood factors are important in determining susceptibility to nephropathy. ${ }^{34}$

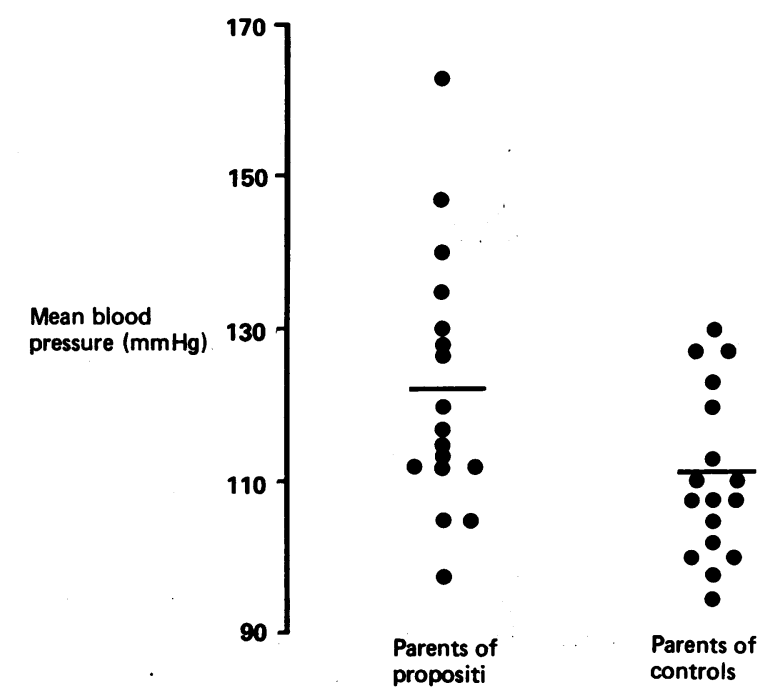

Mean blood pressure in the parent with higher arterial pressure of 17 proteinuric (propositi) and 17 non-proteinuric (controls) diabetic patients. Bars are means.

Difference between sample means $11 \mathrm{~mm} \mathrm{Hg}(95 \%$ confidence interval 1.7 to $20.3 \mathrm{~mm} \mathrm{Hg} ; t=2 \cdot 6, \mathrm{df}=16, \mathrm{p}<0.02$ ).

Our findings suggest that factors associated with raised arterial pressure in non-diabetic family members may play a part in the liability to nephropathy in the insulin dependent member. The raised mean pressures in the parents of the diabetics with nephropathy were unlikely to have arisen from observer bias, as the observations were made without knowledge of the patient's blood pressure and proteinuric state. Nor is there reason to suppose that selection by mortality reduced the representation of higher pressures among the parents of non-proteinuric diabetics. The death rate was at least as high among parents of proteinuric patients.

In animals and humans genetically prone to essential hypertension renal haemodynamic disturbances similar to those of insulin dependent diabetics at risk of nephropathy may be detected before hypertension is evident. ${ }^{21} 22$ This glomerular dysfunction of prehypertension may be the added factor responsible for a more malignant course of diabetic glomerulosclerosis, leading to progressive renal failure. ${ }^{23}$ The operation of such a possible genetic component has recently been suggested by the detection of raised activity of the red cell sodium and lithium countertransport system, currently considered a marker for essential hypertension, ${ }^{24}$ in nephropathic and microalbuminuric insulin dependent diabetics. ${ }^{25} 26$ It would explain the precocious increase of blood pressure seer: in microalbuminuric insulin dependent patients at risk of nephropathy long before there is any hint of renal failure. ${ }^{13-15}$ The mechanism by which a familial tendency to high arterial pressure might be expressed as susceptibility to nephropathy in the diabetic must remain speculative. Nevertheless, there is convincing evidence in animals that the combination of experimental diabetes and arterial hypertension leads to severe renal lesions and progressive renal failure ${ }^{27}$ probably as a result of increased intraglomerular pressure. 
We propose that the susceptibility to nephropathy in insulin dependent diabetics is linked with the liability to raised arterial pressure. This predisposition, as manifested in the parents, is likely to be transmitted genetically, ${ }^{24}$ though mediation through familial sharing of environmental factors cannot totally be excluded..$^{28}$ Interestingly, comparatively low blood pressure is an almost universal feature among long term survivors of uncomplicated diabetes. ${ }^{29}$

We thank Mr T Murrells and Mr F House for statistical advice, Mrs J Gray for secretarial help, and the British Diabetic Association for research group support.

\section{References}

1 Andersen AR, Christiansen JS, Andersen JK, Kreiner S, Deckert T. Diabetic nephropathy in type I (insulin dependent) diabetes: an epidemiological study. Diabetologia 1983;25:496-501.

2 Krolewski A, Warram JH, Christlieb AR, Bunsick EJ, Kahn CR. The changing natural history of nephropathy in type I diabetes. Am $\mathcal{F}$ Med 1985;78:785-94.

3 Pirart J. Diabete et complications degeneratives: presentation d'une etude prospective portant sur 4,400 cas observe entre 1947 et 1973. Diabete Metab 1977;3:97-107, 173-82, 245-56.

4 Deckert T, Poulsen JE. Diabetic nephropathy: fault or destiny? Diabetologia 1981;21:178-83.

5 Mauer SM, Steffes MW, Ellis EN, Sutherland DER, Brown DM, Goetz FC. Structuralfunctional relationships in diabetic nephropathy. $\mathcal{F}$ Clin Invest 1984;74:1143-55.

6 Barnett A, Mijovic C, Fletcher J, et al. Low plasma C4 concentrations: association with microangiopathy in insulin-dependent diabetes. BrMed 7 1984;289:943-5.

7 Mijovic C, Fletcher JA, Bradwell AR, Barnett AH. Phenotypes of the heavy chains of immunoglobulins in patients with diabetic microangiopathy: evidence for an immunogenetic pre-disposition. BrMed J 1986;292:433-5.

8 Cooper ME, Duff R, Buchman R, McPherson J, Jerums G. Low serum C4 concentrations and microangiopathy in type I and type II diabetes. Br Med $\mathcal{f}$ 1986;292:301.

9 Cudworth AG, Bodansky HJ. Genetic and immunological factors in diabetic complications. In: Keen H, Jarrett RJ, eds. Complications of diabetes. 2nd ed. London: Edward Arnold, 1982:1-12.
10 Parving HH, Smidt UM, Frisberg B, Bonnevie-Nielsen V, Andersen AR. A prospective study of glomerular filtration rate and arterial blood pressure in insulin-dependent diabetics with diabetic nephropathy. Diabetologia 1981;20:457-61.

11 Drury PL. Diabetes and arterial hypertension. Diabetologia 1983;24:1-9.

12 Keen H, Track NS, Sowry GSC. Arterial pressure in clinically apparent diabetics. Diabete Metab 1975;1:159-78.

13 Wiseman MJ, Viberti GC, Mackintosh D, Jarrett RJ, Keen H. Glycaemia, arterial pressure and microalbuminuria in type I (insulin-dependent) diabetes mellitus. Diabetologia 1984;26:401-5. 14 Mathiesen ER, Oxenboll D, Johansen K, Svendsen PA, Deckert T. Incipient nephropathy in type I insulin-dependent diabetes. Diabetologia 1984;26:406-10.

15 Mogensen CE, Christensen CK. Predicting diabetic nephropathy in insulin-dependent patients. N Engl f Med 1984;311:89-93.

16 Viberti GC, Hill RD, Jarrett RJ, Argyropoulos A, Mahmud U, Keen H. Microalbuminuria as a predictor of clinical nephropathy in insulin-dependent diabetes mellitus. Lancet 1982;i:1430-2. 17 Pickering GW. High blood pressure. 2nd ed. London: J \& A Churchill, 1968:236-73.

18 Black DAK, Cameron JS. Renal function. In: Brown SS, Mitchell PL, Young DS, eds. Chemical diagnosis of disease. Amsterdam: Elsevier, 1979:453-524.

19 Cox DR. Analysis of binary data. London: Methuen \& $\mathrm{Co}, 1970$.

20 Thomsen AC. The kidney in diabetes mellitus. Copenhagen: Munksgaard, 1965. (Thesis.)

21 Bianchi G, Cusi D, Guidi E. Renal hemodynamics in human subjects and in animals with genetic hypertension during the pre-hypertensive stage. Am $\mathcal{F}$ Nephrol 1983;3:3-79.

22 Sandahl-Christiansen J, Gammelgaard J, Frandsen M, Parving HH. Increased kidney size, glomerular filtration rate and renal plasma flow in short-term insulin-dependent diabetics. Diabetologia 1981;20:451-6.

23 Thomsen OF, Andersen AR, Christiansen JS, Deckert T. Renal changes in type I (insulindependent) diabetic patients with and without clinical nephropathy: a light microscopic, dependent) diabetic patients with and without clinical nephropathy:

morphometric study of autopsy material. Diabetologia 1984;26:361-5.
24 Hilton PJ. Cellular sodium transport in essential hypertension. N Engl f Med 1986;314:222-9.

24 Hilton PJ. Cellular sodium transport in essential hypertension. $N$ Engl J Med 1986;314:222-9.
25 Mangili M, Bending JJ, Scott G, Li LK, Gupta A, Viberti GC. A marker for diabetic Mangili M, Bending JJ, Scott G, Li LK, Gupta A, Viberti GC. A marker for diabetic
nephropathy. Increased red cell $\mathrm{Na}^{+} / \mathrm{Li}^{+}$exchanger activity. Diabetes 1987;36 (suppl 1):43A.

26 Krolewski A, Rand L, Canessa M, Phillips L. Genetic predisposition to hypertension is a risk factor for renal but not eye complications in IDD. Diabetes 1987;36(suppl 1):106A

27 Mauer SM, Steffes MW, Azar S, Sandberg SK, Brown DM. The effects of Goldblatt hypertension on development of the glomerular lesions of diabetes mellitus in the rat. Diabetes 1978;27:738-44.

28 Speers MA, Kasl SV, Freeman DH, Ostfeld AM. Blood pressure concordance between spouses. Am f Epidemiol 1986;23:818-29.

29 Borch-Johnsen K, Nissen RN, Nerup J. Blood pressure after 40 years of insulin-dependent diabetes. Diabetic Nephropathy 1985;4:11-2.

(Accepted 29 June 1987)

\title{
Controlled multicentre therapeutic trial of an unrefined carbohydrate, fibre rich diet in Crohn's disease
}

\author{
JEAN K RITCHIE，JANE WADSWORTH， J E LENNARD-JONES， ELIZABETH ROGERS
}

\begin{abstract}
Between 1 September 1980 and 31 August 1983, 352 patients with inactive or mildly active Crohn's disease but not taking drug treatment apart from sulphasalazine were entered from 40 hospitals into a prospective trial to assess the effects of two different diets on disease activity over two years. One hundred and sixty two patients were randomly allocated to take a diet unrestricted in sugar and low in fibre and 190 to a diet with little or no sugar and high in unrefined carbohydrate.

No clear difference in clinical course was detected among patients who accepted the two different types of dietary advice.
\end{abstract}

\section{St Mark's Hospital, London EC1V 2PS}

JEAN K RITCHIE, DM, MRCP, senior research fellow

J E LENNARD-JONES, MD, FRCP, consultant gastroenterologist

\footnotetext{
Academic Department of Community Medicine, St Mary's Hospital Medical School, London

JANE WADSWORTH, MSC, lecturer in medical statistics

St Bartholomew's Hospital, London

ELIZABETH ROGERS, BSC, SRD, chief dietitian

Correspondence to: Professor Lennard-Jones, St Mark's Hospital.
}

\section{Introduction}

One of the most difficult features of Crohn's disease is its chronicity and tendency to recur after resection. A harmless treatment which decreased the relapse rate after medical or surgical treatment would represent real progress. Many studies have shown that patients with Crohn's disease tend to eat more sugar, ${ }^{1-8}$ and one study also showed less raw fruit and vegetables, ${ }^{4}$ than healthy control subjects. A retrospective comparison suggested that the clinical course of 32 patients treated with a diet low in refined carbohydrate and high in unrefined cereals, vegetables, and fruit was more favourable than that of a matched group of patients treated without dietary modification.'

We report the results of a randomised prospective single blind trial over two years of two types of dietary advice given to patients with Crohn's disease who were well despite the presence of diseased intestine or after resection. One group of patients was advised to avoid refined carbohydrate and to replace it with unrefined carbohydrate. This change resulted in increased dietary fibre but a fibre supplement was not advised. The other group was advised to avoid unrefined cereal foods but was given no advice to alter the consumption of refined carbohydrate.

\section{Patients and methods}

Selection of patients-Criteria for the diagnosis of Crohn's disease were based on a typical clinical history with characteristic appearances in radiographs or at laparotomy and whenever possible confirmed by biopsy or 